\title{
Local Development Planning Process: A Policy-Level Analysis in Nepal
}

\author{
Bhaba Datta Sapkota (PhD Scholar)* \\ Indra Mali Malakar (PhD Scholar)*
}

\begin{abstract}
This study aims at assessing the process and practice of local development planning in Nepal under federal system, with the bid of analyzing the local government operation act, 2074 and local level plan formulation direction, 2075. Using the primary and secondary sources of data, the study embarks on the local development planning process under federal system of Nepal while employing a descriptive research design. Nepal has not experienced long empirical experiences on local development planning exercised under federal democratic republic and it is a totally new practice. The study argues that the local government operation Act, enacted in 2074, conceived the decentralized planning process starting from the settlement level moving up through the local government to the national level and under this all local bodies are required to prepare short, medium and long term, periodic and strategic plans. It concludes that the long term vision of $15^{\text {th }}$ plan of Nepal with 'Prosperous Nepal, Happy Nepali' is the foundation for upgrading high income countries by transforming Nepal into socialist oriented public welfare with a rich economy social justice and peaceful living considering local development plan as yardstick and pivot for national long term vision.
\end{abstract}

Key words: Palika, participation, planning, process \& output.

\section{Introduction}

The idea of planning became very popular after the end of the 1930's great economic depression and World War Second (1945) when developed but disrupted countries had to be rehabilitated and the underdeveloped countries were passionate about the objective of

${ }^{*}$ Mr. Sapkota is a Lecturer at the Department of Rural Development, Patan Multiple Campus, TU, Lalitpur.Email: bdsapkota78@gmail.com

${ }^{*}$ Mr. Malakar is a Lecturer at the Department of Population Studies, Patan Multiple Campus, TU, Lalitpur.Email: indraamali1982@gmail.com. 
rapid economic development. The origin of long-term planning goes back to USSR where 'GOELRO' plan (1920-35) was formulated and implemented in 1920 AD for the first time. The concept of economic planning has attracted the attention of most developing countries since its first experiment made by the Soviet Union in 1928 AD (Nepal, 2008).

The history of development planning in Nepal is not so long. The annual budgeting system was introduced in 1951 AD for the first time in Nepal. King Mahendra announced the Royal Declaration in 1955 AD, later on it became a draft for the five-year plan. On $20^{\text {th }}$ Paush, 1956 A.D. a planning commission was formed. All sorts of past efforts ultimately became the foundation of the development plan. Ultimately, the first five-year plan (19561961) was introduced in 1956 AD in Nepal (Singh \& Sapkota, 2073).

A predesigned course of action and set of activities to operate in a systematic way to achieve definite targets/goals and objectives is colloquially called plan. It is an intellectual process characterized by thinking before doing. Plan is, therefore, a vision to go to a particular destination within a time horizon. The process of making a plan to achieve definite goals and deciding in advance what is to be done, when, where, how and by whom it is to be done is a spirit of plan. It bridges the gap from where we are now and where we want to go.

Indeed, planning is a comprehensive term that focuses on growth, allocation and utilization of resources in a planned way to capture settled objectives of development. It is a process, which encompasses vision, mission, goals, objectives, strategies, working policies, and relevant programmes, on the one hand, and identifies existing potential resources and implementation capabilities to achieve the goals and objectives over a specific period, on the other. Planning is directly associated with the people's lives and livelihoods. It is a measuring rod of nat ional prosperity and human well-being. To succeed in the planning, there should be logical linkage among the elements of planning; otherwise, the expected result would not be achieved, consequently, the entire effort and resources will be misleading.

Different approaches to planning have been practiced all over the world; although the typologies are unlike according to the governing system adopted by the economies. For instance, capitalistic planning, socialistic planning and planning under mixed economy are common and used to practice in global economic system. Under these three major spheres of planning exercises, other forms of planning have been adopting by the economies according to their governing system, economic system and ruling pattern. For instance, top-down planning, bottom-up planning, regional planning, physical planning, frictional planning, cyclical planning, corrective planning, sectoral planning, micro-planning, and so forth. 
The top-down and the bottom-up approaches are so widely used in the process of planning, depending upon the forms of governing. State-controlled or socialist economies, for instance, China, Vietnam, Cuba, Laos, Russia, etc followed the top-down approach to planning. Generally, top-down planning exercise has an inherent feature to making people dependent on the government. The top-down approach to planning and development tries to providing instead of promoting the local people (Karna, 2007).Contrary to this concept; many developing democratic economies including Nepal strictly follow the bottom-down approach to development and planning exercise mainly after 1970, a turning point of alternative development discourse. This paper is wholly guided by the alternative development theories (people's participation, inclusion and self-reliance). The first motto of participatory theory (local development planning) is where people use participatory tools and come up with priorities based on pre-determined interventions. In this process local people lead and make decision in the planning process. It gives a sense of ownership to the local real beneficiaries and enables them to decide what is right and wrong for their individual life. The tenet of local development planning is promoting instead of providing (Sundaram, 2009).

Local development planning (LDP) is people's participation in planning process. It is; therefore, a people centered action and gather data using participatory tools, analyses data, prepare plans and set priorities. LDP facilitates implementation in an orderly manner to achieve the pre-designed vision, mission, and goals and set objectives. Further, it enables appraisal of scarce resources available in the economy through a comprehensive study to avoid existing socio-economic challenges and assists in knowing the local people's wants, desires, and demands. LDP implies that it always stimulates optimum allocation of scarce resources, facilitates timely implementation of programmes, projects, and activities (IUCN \& PBWB, 2011). Thus, LDP is a tool that helps to address the felt needs of local beneficiaries by creating opportunities for specific marginalized and disadvantaged groups, such as small farmers, poor class, women, minorities, Dalit, and the landless. Indeed, LDP exercise enhances political commitment and institutional support for optimum use of scarce resources by building a common understanding between local people and development stakeholders. Put simply, local development planning is a process whereby stakeholders play an active role in decision making and in the consequent activities which affect them (IUCN \& PBWB, 2011). This paper is limited on policy level analysis with less focus on empirical evidence and includes procedure of planning at local level (Palika level only) and has analyzed, and interpreted the result, according to the local government operation Act, (2074) whereas the study does not deal the process and issues of federal and provincial level planning procedure. 


\section{Objective}

The main objective of this paper is to examine the process of local development planning process in Nepal under federal system.

\section{Method and Data Sources}

Methodologically, this paper has used the content analysis as a secondary data technique by reviewing and analyzing the current policy documents. The convenience of this method is that, it enables the researcher to draw the views from the secondary data produced, concerning the process of local development planning in Nepal and covering on policy including local government operation Act (2074) and local level plan formulation direction (2075), and study limits only on stages of local development planning at Palika level. Other research techniques used are: descriptive research design, narrative analysis, table and flow chart used for data presentation and analysis with the paper's scope limited to Nepalese perspective under federal system.

\section{Results}

\section{Process of Local Development Planning}

Local development planning exercise under federal democratic republican state in Nepal is newly practice and has not its long empirical experiences. Although LDP is a process whereby local real beneficiaries organize themselves and define their felt needs, prioritize problems and issues, develop objectives and set the strategies and working policies. They involved in implementation phase, monitor and evaluate their plans. All development stakeholders, working in local level, had a provision to involve in the process of local development planning, resource mobilization and service delivery with the concerned local bodies. It is a technique, process and means with the realization of certain pre-determined and well-defined goals and objectives set-up by the concerned authority, mainly central planning authority. Indeed, while formulating a local development planning, planners shall follow the definite method, process and action. To make the plan formulation process easy, the different subjective committees are constituted. The subjective committee shall be formed as per the following areas of coverage. 
Table 1: Subjective committees formed at local level

\begin{tabular}{|c|l|l|}
\hline S.N. & \multicolumn{1}{|c|}{$\begin{array}{c}\text { Subjective } \\
\text { Committee }\end{array}$} & \multicolumn{1}{c|}{ Committee Related Sub-sector } \\
\hline 1. & $\begin{array}{l}\text { Economic } \\
\text { Development }\end{array}$ & $\begin{array}{l}\text { Agriculture, industry, commerce and trade, tourism, } \\
\text { cooperative and financial sector. }\end{array}$ \\
\hline 2. & $\begin{array}{l}\text { Social } \\
\text { Development }\end{array}$ & $\begin{array}{l}\text { Education, health, drinking water and sanitation, culture, } \\
\text { gender equality and social inclusion. }\end{array}$ \\
\hline 3. & $\begin{array}{l}\text { Infrastructure } \\
\text { Development }\end{array}$ & $\begin{array}{l}\text { Road and bridge, suspension bridge, irrigation, building } \\
\text { and urban development, energy, micro hydro-power, } \\
\text { alternative energy and communication }\end{array}$ \\
\hline 5. & $\begin{array}{l}\text { Forest, } \\
\text { anvironment } \\
\text { Management }\end{array}$ & $\begin{array}{l}\text { Forest and land conservation, watershed conservation, } \\
\text { environmental conservation, climate change, drainage } \\
\text { management, disaster management etc. }\end{array}$ \\
\hline $\begin{array}{l}\text { Institutional } \\
\text { Development and }\end{array}$ & $\begin{array}{l}\text { Human resource development, institutional capacity } \\
\text { development, determining the criteria for service delivery, } \\
\text { use of electric communication in service deliverymechanism, } \\
\text { fund mobilization, financial discipline, accounting and } \\
\text { internal control, final accounting and other. }\end{array}$ \\
\hline
\end{tabular}

Source: Local Level Plan Formulation Direction, 2075

Thus, local development plan should be formulated with a clear framework for the holistic and balanced development of various sectors of local economy such as primary (agriculture), secondary (industry) and tertiary (service) and dimensions of local development i.e. social, cultural, economic, political, environmental, human an physical. The local government operation Act, enacted in 2074, conceived the decentralized planning process, starting from the settlement level moving up through the Rural Municipality (RM), Municipality (M) and District Coordination Committee (DCC) to the national level. All local bodies are required to prepare short-term, medium-term, long-term, periodic and strategic plans.

\section{Sequence and Order of Local Development Planning}

Plan formulation process is in sequential order. Development plan or local development plan shall go ahead via define, dream, develop, design and plan. The sequential order shall be as per the following chart (figure 1). 
Figure: 1 Sequence Order of Plan Formulation Process

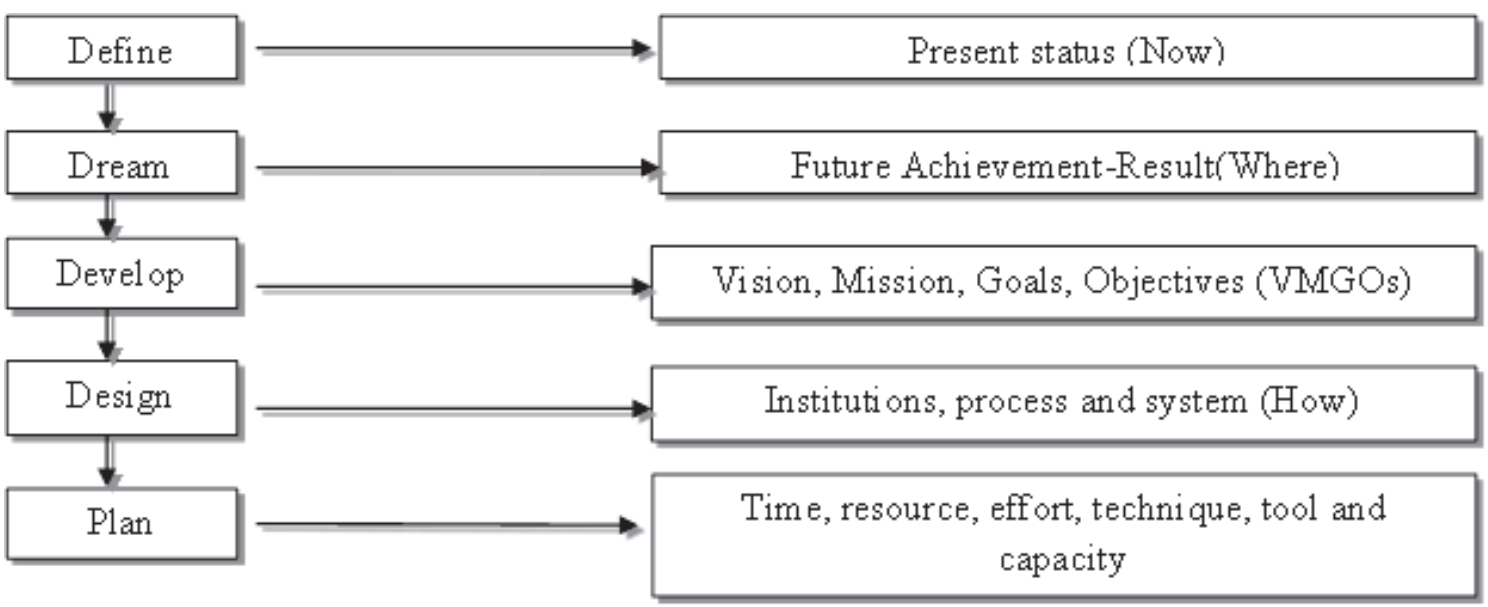

Source: Sapkota \& Adhikari, 2021

The local government operation Act, (2074) provides for a bottom-up planning process for local bodies at each level, starting at the settlement level. It is more popularly known as the 8 -step planning process, in which the involvement and participation of the community, government and civil society stakeholders is expected. The planning cycle follows a timebound and eight stages (figure 2).

Figure 2: Local Development Plan Formulation Process

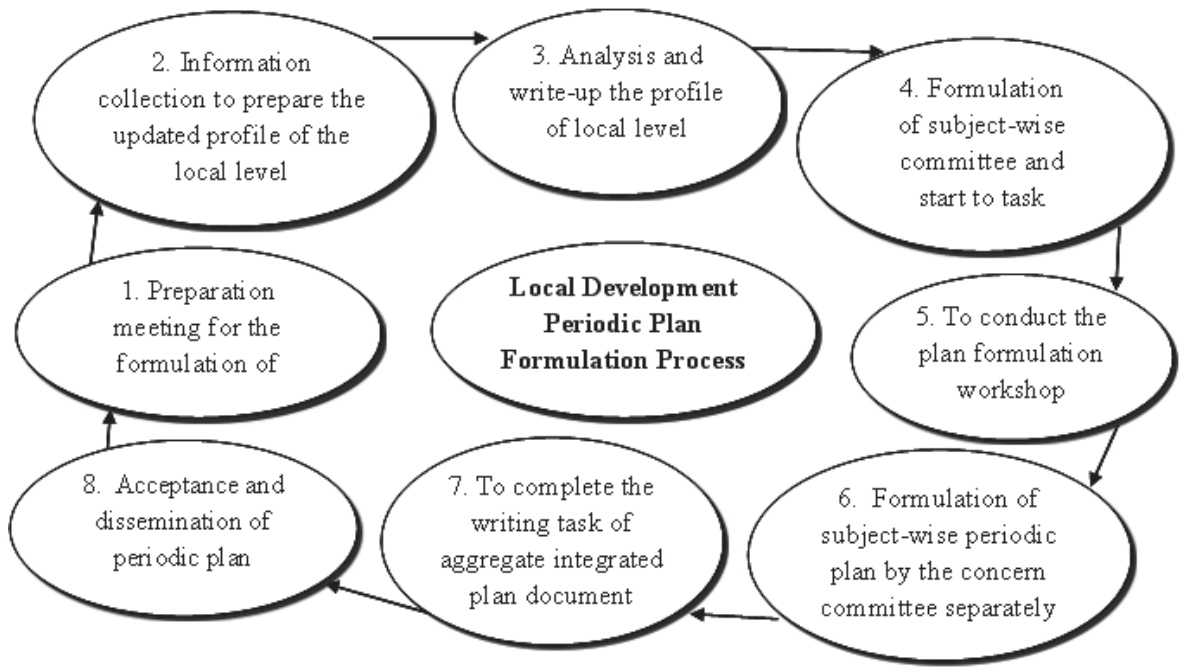

Source: Local Level Plan Formulation Direction, 2075 
Going through these eight stages, local government shall develop the local development plan formulation process begins from the month of Bhadra and is accomplished by the month of $15^{\text {th }}$ Paush. The entire process is led by the Chairperson and Mayor of rural municipality and municipality respectively. Local governance is the set of institutions and mechanism regarding the process of planning, implementing, maintaining, evaluating and monitoring the affairs that have impact on local population. Hence, it incorporates an established mechanism to determine and implement public choices and decisions at the local level. Local government must follow the above mentioned eight stages while developing a periodic plan at local level.

\section{Discussion}

The planning involves activities ranging from need identification to post-implementation management, maintenance and repair and administration of completed projects. The process also involves mechanisms and procedures for inspection, review, supervision, monitoring, evaluation and handover of completed projects or programs. The planning cycle involves many processes, such as setting priorities, resource mapping, feasibility studies and discussion with the subjective committee. The deep coordination with other line agencies, federal government, provincial government, district co-ordination committee, non-government organizations, national planning commission and private sectors must be inevitable. According to the guidelines of Local Self-Governance Act (1991), all local government bodies should have to oblige to conduct a participatory development planning process. The $15^{\text {th }}$ Plan of Nepal is the basis for achieving the long-term vision of "Prosperous Nepal, Happy Nepali". Under this, the national goal of the scheme is to build a foundation for upgrading high-income countries by transforming it into socialistoriented public welfare with a rich economy social justice and peaceful living. For this local development plan is considered as a yardstick and pivot for national long-term vision. In the United States, local governments are interested in development policy because of changing domestic and international environment (Blakely \& Bradshaw, 2002). In the domestic environment, these changes are related to the economic recession, the rise of taxes, the federal budget deficit and the cutback of federal aid, which have forced local governments to find the additional resources. In China, local development issues have been closely related to the reform and opening up policies that have emphasized since the late 1970s. These policies have gradually changed the Chinese economic system and have successfully improved economic performance in China. Many reform policies have been introduced in selected local governments and then gradually expanded to other regions based on the success of local experiences (Liou, 2009). 


\section{Conclusion}

The local government should remain at the forefront of the entire planning process and ensure the local beneficiaries while setting the vision, mission, goals, and objectives in a sequential order. Local development planning process in Nepal involves designing the overall process, steps and procedures as guided and direction of policy documents. According the policy provision under federal system eight key steps must crossed while developing the periodic local development planning.

Every local government should consider the spirit of local development to follow the concept of result-based planning mechanism because it always focuses more on the results in terms of input, process, outcome and impact of the plan. The result-based planning gives importance to strategy as to how it could be realized by looking at different alternatives and develops policies and programs to realize the goals and targets in reality. Result framework should be used to check the consistency in the input, process, output, outcome and impact. Therefore, each local development planning should follow the principles of result-based or performance-based planning including transparency, accountability, efficacy, efficient, participation and proactive management. Finally, the policies should be introduced and implemented in succession for the successes and should be expanded gradually in other regions immediately based on the success on local experiences.

\section{Acknowledgements}

Our special thanks go to anonymous reviewers and editor who support to improve the quality of this paper.

\section{References}

Blakely, J. E., \& Bradshaw K. T. (2002). Planning local economic development: Theory and practice. Sage Publications, Thousand Oaks, London and New Delhi.

Government of Nepal (GoN). (1999). Local self-governance act, 1999. LOCAL SELFGOVERNANCE ACT, 2055 (1999) (lawcommission.gov.np)

Government of Nepal (GoN). (1999). Local self-governance regulation,1999. Local Self Gov. Rule (Book) (mofald.gov.np).

Government of Nepal (GoN). (2017). The Local Government Operational Act, 2017. Ministry of Law, Justice and Parliamentary Affairs

International Union for Conservation of Nature (IUCN), \& Pangani Basin Water Board 
Pangani (PBWB). (2011). Module 1: Participatory planning, stakeholder participation and gender mainstreaming an integrated water resources management and development. Gland, Switzerland.

Karna, S. K. (2007). Economic planning: Theory and practice. Quest Publication.

Lekhi. R. K. (2001). The economics of development and planning. India: Kalyani Publishers.

Liou, K. T. (2009). Local economic development in China and the United States: Strategies and issues. Public administration review, 69.

National Planning Commission (NPC). (2075). Local level plan formulation direction, 2075. Government of Nepal, National Planning Commission.

National Planning Commission (NPC). (2076). The 15 th plan (2076/77-2080/81). Government of Nepal.

Nepal, G. (2008). Developing planning in the era of globalization. Himalaya Book Stall.

Sapkota, B. D., \& Adhikari, R. R. (2021). Introduction to rural development. Vidyarthi Pustak Bhandar, Kathmandu, Nepal.

Singh, M., \& Sapkota, B. D. (2073). Development theories and planning in rural perspectives. Quest publication Pvt. Ltd.

Sundaram, I. S. (2009). Rural development: A textbook for university and college students. Himalaya Publishing House Pvt. Ltd. 